\title{
Effects of Maternal Protein Malnutrition on Fetal Growth, Plasma Insulin-like Growth Factors, Insulin-like Growth Factor Binding Proteins, and Liver Insulin-like Growth Factor Gene Expression in the Rat
}

\author{
SÉVERIN M. MUAKU, VÉRONIQUE BEAULOYE, JEAN-PAUL THISSEN, \\ LOUIS E. UNDERWOOD, JEAN-MARIE KETELSLEGERS, AND \\ DOMINIQUE MAITER
}

Unité de Diabétologie et Nutrition, University of Louvain School of Medecine, B-1200 Brussels, Belgium [S.M.M., V.B., J.-P.T., J.-M.K., D.M.]; and the Department of Pediatrics, Division of Endocrinology, University of North Carolina, Chapel Hill, North Carolina 27599 [L.E.U.]

\begin{abstract}
We examined the effects of maternal dietary protein restriction on fetal growth and expression of IGF-I and -II, and IGF-binding proteins (IGFBP). We sought to dissociate the respective effects of maternal protein versus calorie restriction on growth indices and IGF synthesis by the neonates of proteinrestricted dams. Pregnant Wistar rats (six to eight per group) fed a low (5\%) protein diet throughout gestation had impaired body weight gain compared with controls fed a normal (20\%) protein diet (by $45 \%, p<0.001$ ). Their serum and liver IGF-I concentrations and liver IGF-I mRNA concentrations were also reduced by 60,80 , and $50 \%$, respectively. Serum IGFBP-3 was reduced by $60 \%$ in protein-restricted dams within 1 to $2 \mathrm{~h}$ after delivery ( $p<0.001$ versus controls), although IGFBP-1, -2 , and -4 were not significantly affected by the dietary protein intake. In pups of protein-restricted dams, the mean body and liver weight at birth was $15-20 \%$ less than that observed in the progeny from normal protein-fed dams $(p<0.01)$. Their plasma and liver IGF-I concentrations were 30 and $60 \%$ lower, respectively, whereas liver IGF-I mRNA abundance was reduced by $50 \%(p<0.01)$. In contrast, neonatal plasma IGF-II and liver IGF-II mRNA
\end{abstract}

concentrations were not significantly affected by the maternal protein malnutrition. Also, the plasma levels of IGFBP were not altered in the growth-retarded pups. Maternal protein restriction did not affect fetal and placental growth, plasma and liver IGF-I levels, and liver IGF-I mRNA abundance in 20-d-old fetuses. We conclude that intrauterine growth retardation caused by maternal protein malnutrition is associated with reduced neonatal expression of the IGF-I gene without obvious changes in IGF-II gene expression and plasma IGFBP concentrations. These results support the emerging evidence that IGF-I may play a role in the regulation of fetal growth and development. (Pediatr Res 37: 334-342, 1995)

IGFBP, IGF binding protein

GH, growth hormone

ANOVA, analysis of variance

IUGR, intrauterine growth retardation

BW, body weight
IGF-I and IGF-II promote growth during postnatal life (1). There is also evidence that the IGF may regulate fetal growth and differentiation. IGF and their mRNA are present in most fetal tissues (2-4); specific IGF receptors and IGFBP are widely expressed during fetal life (5); and IGF exert mitogenic

Received January 26, 1994; accepted September 19, 1994.

Correspondence: D. Maiter, M.D., Unité de Diabétologie et Nutrition UCL-DIAB/ 54.74, Avenue Hippocrate 54, 1200 Bruxelles, Belgium.

Supported by a grant from the Administration Générale de la Coopération au Développement to S.M.M. (AGCD no. 907928), by grants from the Belgian National Fund for Scientific Research (nos. 3.4544.87 and 3.4559.93), from the Fund for Scientific Development, University of Louvain (Belgium), and from the National Institutes of Health, Research Grant HD 26871. and differentiative effects on fetal cells in vitro (5). Decreased serum concentrations of IGF-I are observed in growth-retarded animal or human fetuses or neonates (6-12). Furthermore, two recent reports show that newborn mice bearing a targeted disruption of the IGF-I and IGF-II genes exhibit severe growth deficiency $(13,14)$.

Nutrition is an important regulator of IGF-I and IGFBP during postnatal and fetal life. Restriction of energy or protein in humans and animals leads to significant reductions in serum concentrations of IGF-I $(15)$ and IGFBP-3 $(16,17)$, and in liver IGF-I peptide and mRNA $(18,19)$. Liver IGFBP-1 and -2 expression, however, is increased by dietary restriction $(20$, 
21). Decreased serum IGF-I and increased liver IGFBP-1 mRNA are also observed in growth-retarded fetuses after maternal uterine artery ligation (7) or fasting (9). Nutrition, however, does not appear to influence fetal IGF-II expression $(7,8)$.

Maternal protein restriction stunts fetal somatic and organ growth (22), and reduces fetal serum IGF-I concentrations (23). In our study, we examined the effects of maternal dietary protein restriction on growth, plasma IGF-I, IGF-II, and IGFBP, and on liver expression of the IGF genes in fetal rats at two different times of gestation-2 $\mathrm{d}$ before delivery and at birth. Because preliminary experiments showed that proteinrestricted dams decrease their food intake during late gestation, we sought to dissociate the respective effects of maternal protein versus calorie restriction on the growth indices of the neonates.

\section{METHODS}

Animals. Pregnant Wistar rats (dams) were purchased from KUL laboratories (Leuven, Belgium). The day of initiation of pregnancy was determined by the presence of a vaginal plug after overnight mating, and was designated as $\mathrm{d} 0$ of gestation. Upon arrival at $\mathrm{d} 0$, the rats were weighed (initial BW: $210-230 \mathrm{~g}$ ) and randomly assigned to one of two powdered diets: a normal protein diet ( $20 \%$ casein; P20) or a low protein diet (5\% casein; P5; U.A.R., Villemoisson-sur-Orge, France). Both diets were isocaloric $(325 \mathrm{cal} / 100 \mathrm{~g})$ and contained similar amounts of fat $(5 \%)$, cellulose $(17 \%)$, and essential minerals and vitamins (8\%). Animals were housed individually in metabolic cages under controlled conditions of lighting $(0600-1800 \mathrm{~h})$ and temperature $\left(22 \pm 2^{\circ} \mathrm{C}\right)$, and had free access to tap water. BW and food intake were recorded daily, and dams that failed to gain weight normally were excluded from the studies. Near parturition (d 22 of gestation), dams were observed every $1-2 \mathrm{~h}$ to determine the time of delivery accurately.

Experimental design. In experiment 1, dams were fed ad libitum either the normal protein diet (P20; controls; $n=6$ ) or the low protein diet $(\mathrm{P} 5 ; n=7)$ throughout gestation until delivery (d 22 of gestation).

In experiment 2 , dams were also fed ad libitum either the control diet (P20; controls; $n=9$ ) or the protein-restricted diet $(\mathrm{P} 5 ; n=8)$ until d 20 of gestation. They were killed at that time and the fetuses were removed by cesarean section.

In experiment 3 , dams were divided into three groups. The first group (P20; controls; $n=6$ ) was fed the normal protein diet ad libitum throughout gestation. The two other groups (pair-fed groups) received either the normal protein diet (PF20 group; $n=6$ ) or the low protein diet (PF5 group; $n=8$ ) in isocaloric amount. This quantity was determined daily from the group of rats having the lowest food consumption (PF20 group from d 0 to 17; PF5 group from d 18-22). Dams and their corresponding litters were killed by decapitation, either on $\mathrm{d} 20$ of gestation (experiment 2) or within 1-2 h after parturition (experiments 1 and 3). Each fetus or neonate was quickly weighed and dissected. Blood was collected from trunk vessels into glass tubes for dams or heparinized tubes for litters. Serum or plasma was stored at $-20^{\circ} \mathrm{C}$ until assayed for IGF-I and IGF-II. Maternal livers and placentas and fetal or neonatal livers were removed and weighed. The number of fetuses or neonates in each litter was recorded, and plasma and livers were each pooled to provide one sample per litter. One fragment of each liver sample was quick-frozen in liquid nitrogen and stored at $-70^{\circ} \mathrm{C}$ for later determination of IGF-I content and mRNA studies. The remaining portion of the liver was homogenized in ice-cold $0.3 \mathrm{M}$ sucrose $(10 \%$, wt/vol) buffered at $\mathrm{pH} 7.4$ with $3 \mathrm{mM}$ imidazole- $\mathrm{HCl}$ as described previously (24). The homogenates were stored at $-20^{\circ} \mathrm{C}$ until assayed for protein and DNA contents by the methods of Lowry et al. (25) and Karsten and Wollenberger (26), respectively. This study was approved by the Institutional Animal Care and Use Commitee of the University of Louvain at Brussels.

RIA. Immunoreactive IGF-I and IGF-II were measured in serum or plasma using a nonequilibrium $\operatorname{RIA}(24,27)$. Values are reported in $\mathrm{ng} / \mathrm{mL}$ using pure plasma-derived human IGF-I or IGF-II as standard. IGFBP in dam sera were separated from IGF-I using the C18 Sep-pak cartridge (Waters Associates, Milford, MA) chromatography $(27,28)$. Because the C18 cartridge chromatography might not remove IGFBP from fetal plasma efficiently enough and the dose-response curves of the eluates were not parallel in the IGF-II assay, fetal samples were prepared for assay by acid Sephadex G-50 column chromatography (29). Rat GH was measured in a double-antibody RIA (24) using the reagents provided by the NIDDK Rat Pituitary Hormone Distribution Program. Results are expressed in terms of the National Institutes of Health RP-2 reference preparation. The RIA for serum/plasma insulin, using rat insulin as standard, was performed as described previously $(24,28)$, except that the second antibody was a solid-phase coupled antiguinea pig $\gamma$-globulin (IRE, Fleurus, Belgium).

Measurement of liver IGF-I peptide concentrations. Liver IGF-I content was determined in dams and litters by RIA (24) after extraction using a method validated for rat tissues (30). Briefly, each liver sample $(50-100 \mathrm{mg})$ was pulverized in a mortar and pestle under liquid nitrogen, mixed with $1 \mathrm{~mL}$ ice-cold $1.0 \mathrm{M}$ acetic acid, vortexed vigorously, and incubated on ice for $2 \mathrm{~h}$. After centrifugation at $20000 \times g$ for $30 \mathrm{~min}$ at $4^{\circ} \mathrm{C}$, the supernatant was transferred to a polypropylene tube and the pellet was reextracted using the same procedure. Both supernatants were combined and dessicated in a speed-vac concentrator (Savant Instruments, Farmingdale, NY). The material was stored at $-20^{\circ} \mathrm{C}$ and reconstituted in assay buffer $24 \mathrm{~h}$ before RIA. The $\mathrm{Hb}$ concentration was also measured by the cyanomethemoglobin method on aliquot of each liver extract reconstituted in Tris buffer, $\mathrm{pH}$ 7.4. The amount of IGF-I in the extract that could have been derived from blood contamination was subtracted from the total extractable IGF-I, as described previously (30). The results are expressed as ng of IGF-I per $\mathrm{g}$ tissue in terms of purified human plasma-derived IGF-I.

RNA preparation and Northern blot hybridization. Total RNA was extracted from the livers of dams (three to four animals per group) and fetuses or neonates (pooled livers from each litter; three to six litters per group) by the guanidine 
thiocyanate/cesium chloride method (31). For litters, a poly $(\mathrm{A})^{+}$RNA-enriched preparation was isolated by three passages of total RNA $(1500 \mu \mathrm{g})$ through an oligo(dT)cellulose column. Total RNA $(20 \mu \mathrm{g})$ or poly(A) ${ }^{+}$RNA (15 $\mu \mathrm{g})$ samples were size fractionated on formaldehyde $/ 1 \%$ agarose gels, and transferred to nylon membranes (Hybond- $\mathrm{N}$, Amersham, Buckinghamshire, UK) by overnight vacuum blotting (VacuGene XL, Pharmacia LKB, Sweden). After UV cross-linking (Stratalinker, Stratagene, La Jolla, CA), the membranes were sequentially hybridized to rat $\left[{ }^{32} \mathrm{P}\right]$-labeled complementary RNA probes specific for IGF-I and IGF-II mRNA, using prehybridization, hybridization, and washing conditions previously reported $(18,32)$.

The specific IGF-I antisense riboprobe was generated from the 194-bp AvaII-Hinfl rat IGF-I exon 3 complementary DNA fragment (33) inserted into the plasmid vector Bluescript (pBS M13 ${ }^{+}$), using uridine $5^{\prime}-\left[\alpha^{-}{ }^{32} \mathrm{P}\right]$ triphosphate (Amersham; 800 $\mathrm{Ci} / \mathrm{mmol}$ ), and T7 RNA polymerase. The 275-bp RsaI rat IGF-II exon 3 complementary DNA fragment (34) subcloned into the vector $\mathrm{pBS} \mathrm{M}_{13}{ }^{+}$was linearized with $E c o \mathrm{RI}$, and a specific ${ }^{32} \mathrm{P}$-labeled IGF-II antisense riboprobe was transcribed using T3 RNA polymerase. Hybridization with a chicken $\left[{ }^{32} \mathrm{P}\right]$-labeled $\beta$-actin complementary DNA, kindly provided by Dr. D. W. Cleveland, was subsequently performed to estimate the variation in RNA loading. Blots were subjected to autoradiography at $-70^{\circ} \mathrm{C}$ using Kodak X-AR films and intensifying screens. Abundance of hybridized mRNA was quantified by scanning of autoradiograms using an LKB Ultroscan XL laser densitometry scanner (LKB-Bromma, Sweden). The results were corrected for $\beta$-actin mRNA and standardized by assigning a value of 100 arbitrary units to hepatic mRNA from control animals. Each individual mRNA value was the mean calculated from two to four different blots run with the same liver RNA preparations.

Measurement of IGFBP. To assess the abundance of serum/ plasma IGFBP, ligand blotting was performed as previously described (16) using PAGE. Electrophoresed proteins were transferred to nitrocellulose membranes that were incubated with a mixture of [ $\left.{ }^{125}\right]$ IGF-I and [ $\left[{ }^{125}\right.$ I]IGF-II, $200000 \mathrm{cpm} / \mathrm{mL}$ each, washed and subjected to autoradiography at $-70^{\circ} \mathrm{C}$. The autoradiograms were scanned using an LKB Ultroscan XL laser densitometry scanner (LKB-Bromma). For each sample, density signals were determined for the 45000-39000 $\mathrm{M}_{\mathrm{r}}$ (IGFBP-3), the $34000-29000 \mathrm{M}_{\mathrm{r}}$ (IGFBP-1 and-2), and the $24000 \mathrm{M}_{\mathrm{r}}$ (IGFBP-4) bands. The 34 000-29000 $\mathrm{M}_{\mathrm{r}}$ bands representing IGFBP-1 and -2 were analyzed together because they could not be reliably separated for quantification by scanning densitometry. The abundance of IGFBP in a pool of sera from normal-fed adult nonpregnant rats served as control. The sizes of radioactive protein bands were estimated by comparison to standards from Bethesda Research Laboratories (Gaithersburg, MD).

Statistical analysis. Data were analyzed by unpaired $t$ test or by one-way analysis of variance, followed by the StudentNewman-Keuls test to compare multiple means. Data are presented as the mean $\pm \mathrm{SEM}$, and $p<0.05$ was considered significant.

\section{RESULTS}

\section{Effects of protein restriction throughout gestation on dams} and newborn pups. Mean daily food intake on $\mathrm{d} 0-17$ of gestation was approximately $20 \%$ higher in rats fed the low protein diet than in control rats ( $\mathrm{P} 5$ versus $\mathrm{P} 20 ; p<0.05$; Fig. $1 A$ ). During the last $5 \mathrm{~d}$ of pregnancy, however, food consumption of the P5-fed dams decreased dramatically to $40 \%$ of the intake of the P20-fed dams $(p<0.05)$. BW gain in P5-fed dams was impaired (45\% decrease at term; $p<0.01$ versus controls; Fig. $1 B$ ), and liver weight and liver protein content were decreased (Table 1). Serum and liver IGF-I concentrations in the P5 dams were, respectively, 56 and $86 \%$ lower than in the P20 dams, whereas their liver IGF-I mRNA abundance was reduced by $50 \%$ (Table 1). Among the circulating IGFBP assayed by ligand blotting, IGFBP-3 (45 000-39000 $\mathrm{M}_{\mathrm{r}}$ band) was markedly reduced (by $60 \%$ ) in the protein-restricted dams within 1-2 h after parturition ( $p<0.001$ versus normal-fed dams), although IGFBP-1, -2 , and -4 were not significantly affected (Fig. 2A).

Maternal protein restriction caused significant growth retardation in the newborn pups without affecting litter size. Body
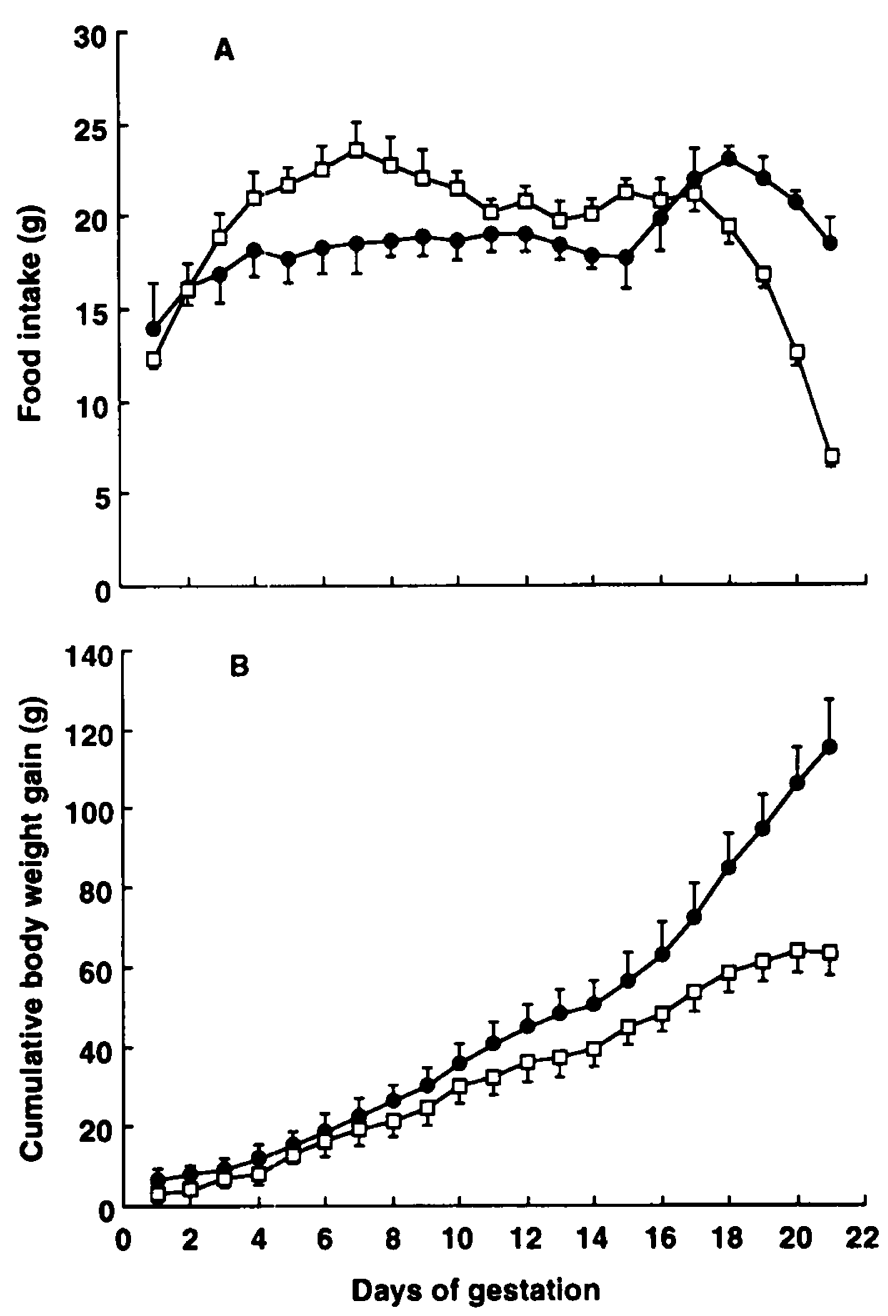

Figure 1. Food intake $(A)$ and cumulative $\mathrm{BW}$ gain $(B)$ in pregnant rats fed ad libitum a normal protein diet (P20, controls; filled circles) or a low protein diet (P5; open squares) throughout gestation. Data are presented as the mean \pm SEM of six to sever rats per group. 
Table 1. Liver wt and protein content, serum and liver IGF-I concentrations, and liver IGF-I mRNA abundance at term in dams fed a normal protein diet ad libitum (P20; controls) or a low protein diet (P5) throughout gestation

\begin{tabular}{cccccc}
\hline Dams & $\begin{array}{c}\text { Liver wt } \\
(\mathrm{g})\end{array}$ & $\begin{array}{c}\text { Protein content } \\
(\mathrm{mg} / \mathrm{liver})\end{array}$ & $\begin{array}{c}\text { Serum IGF-I } \\
(\mathrm{ng} / \mathrm{mL})\end{array}$ & $\begin{array}{c}\text { Liver IGF-I } \\
(\mathrm{ng} / \mathrm{g})\end{array}$ & $\begin{array}{c}\text { Liver IGF-I mRNA } \\
(\% \text { of controls })\end{array}$ \\
\hline P20 & $8.8 \pm 0.5$ & $1898 \pm 91$ & $425 \pm 16$ & $143 \pm 10$ & $100 \pm 6$ \\
P5 & $6.3 \pm 0.2^{*}$ & $1175 \pm 21^{*}$ & $187 \pm 17^{*}$ & $20 \pm 2^{*}$ & $50 \pm 3 \dagger$ \\
\hline
\end{tabular}

Values are shown as the mean \pm SEM of six to seven rats per group, except for liver IGF-I mRNA abundance determined on three rats per group, each individual mRNA value being the mean calculated from two separate Northern blots.

${ }^{*} p<0.001$ vs $\mathrm{P} 20$ controls.

$\dagger p<0.01$ vs $\mathrm{P} 20$ controls.

\section{2-day PREGNANT RATS}

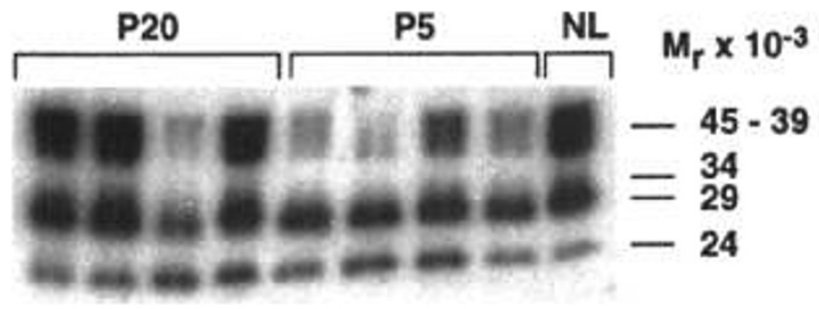

B

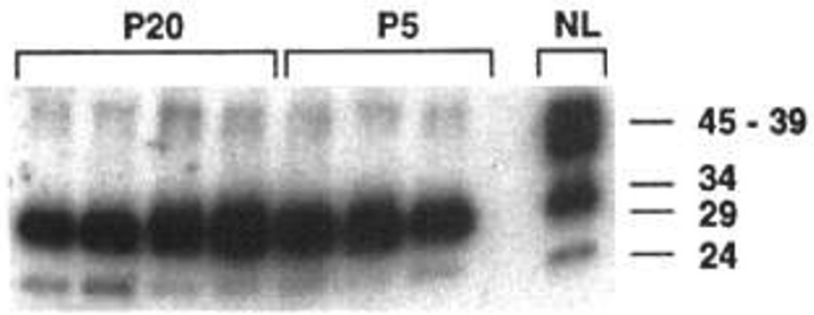

Figure 2. Ligand blot of IGFBP in maternal serum $(A)$ and neonatal plasma $(B)$ collected within 1 to $2 \mathrm{~h}$ after delivery (d 22 of gestation). Pregnant rats were fed either a normal protein diet (P20; controls) or a low protein diet (P5) throughout gestation. A pool of sera from normal fed nonpregnant rats $(N L)$ was used as control. Each well is an individual dam sample $(A)$ or pooled samples of a litter $(B)$. The $\mathrm{M}_{\mathrm{r}}$ of the IGFBP is indicated on the right.

and liver weights of the pups from protein-restricted dams were 15-20\% less than those from normal protein-fed dams $(p<$ 0.01 ; Table 2 ). The reduction in liver weight was predominantly the result of decreased cell number, as indicated by the decrease in the DNA content, without significant change in the protein/DNA ratio (Table 2). Maternal protein deprivation also reduced neonatal plasma and liver IGF-I concentrations, which were, respectively, 29 and $60 \%$ lower than in controls (Fig. $3 B$ ). Total IGF-I mRNA abundance was decreased by $40 \%$ in the liver of pups from P5 dams (Fig. 3B). All IGF-I mRNA species $(7.5,4.7,1.7$, and 1.2-0.7 kb) were decreased to a similar degree (Fig. 3A). When compared with adult pregnant or nonpregnant (NL or normal) rats, the typical pattern of IGFBP in neonatal rat plasma included virtually no IGFBP-3, similar amounts of IGFBP-4, and higher levels of IGFBP-1 and/or -2 (29 000-34000 M band). Maternal protein deprivation during pregnancy did not influence significantly the relative abundance of the various IGFBP species (Fig. $2 B$ ). Similar plasma insulin $(1.06 \pm 0.5$ and $1.02 \pm 0.1 \mathrm{ng} / \mathrm{mL})$ and $\mathrm{GH}$ $(71.8 \pm 7.7$ and $80.0 \pm 4.9 \mathrm{ng} / \mathrm{mL})$ concentrations were also observed in pups from control and malnourished mothers.
Effects of protein restriction from d 0-20 of gestation on dams and fetuses. Pregnant rats fed the low protein diet (P5) ad libitum from d 0 to $\mathrm{d} \mathbf{2 0}$ of pregnancy also exhibited increased food intake during d 0-17 of gestation followed by a sharp decrease from the 18th d onward (data not shown). At d 20, their BW gain and liver protein content were reduced by approximately $40 \%$ compared with controls $(p<0.001$; Table $3)$. Serum and liver IGF-I concentrations and liver IGF-I mRNA abundance in P5 dams were decreased by 56,84 , and $46 \%$, respectively (Table 3 ). Similar relative concentrations of serum IGFBP-1 to -4 were found in control and proteinmalnourished dams, although serum IGFBP-3 levels in control dams were dramatically decreased compared with control nonpregnants rats (data not shown).

Maternal protein restriction from d $0-20$ of gestation did not affect litter size nor indices of growth in 20-d-old fetuses, except for a $27 \%$ decrease in the fetal liver DNA content (Table 4). The mean placental weight was also similar among protein-restricted and normal-fed dams $(0.57 \pm 0.09$ and 0.60 $\pm 0.08 \mathrm{~g}$ in $\mathrm{P} 5$ and P20 dams, respectively). Fetal plasma and liver IGF-I concentrations as well as liver IGF-I mRNA levels were not affected by the maternal protein restriction until $\mathrm{d} 20$ of gestation (Fig. 4). There was also no significant change in fetal plasma IGFBP (data not shown).

Specific effects of maternal protein and calorie restriction on dams and newborn pups. In a third experiment, equivalent daily caloric intakes were ingested by dams fed the $20 \%$ (PF20) and the 5\% (PF5) protein diet (55.6 \pm 2.6 and $55.0 \pm$ $2.6 \mathrm{cal} / \mathrm{d}$, respectively) by first reducing the food consumption of the PF5 group during d 0-17 (by approximately $20 \%$ ), and then by reducing the food consumption of the PF20 group during $\mathrm{d} 18-22$ by approximately $40 \%$. BW gain in PF20 dams remained similar to that of ad libitum P20-fed controls until d 18 and decreased during the last $4 \mathrm{~d}$ of pregnancy; it was $20 \%$ lower at term $(94.5 \pm 4.6$ versus $117.4 \pm 7.5 \mathrm{~g} ; p<0.05)$. However, their liver weight and protein content were similar to the values found in controls (data not shown). The BW gain of dams fed the 5\% protein diet (PF5) was markedly impaired; it was $42 \%$ less at term than that in PF20 dams $(55.1 \pm 5.0 ; p<$ 0.001 ). There was also a $30 \%$ decrease of liver weight and protein content in the PF5 dams, compared with the PF20 values $(p<0.01$, respectively). No significant difference was observed in the serum and liver concentrations of IGF-I nor in the hepatic abundance of IGF-I mRNA between PF20 and P20 control dams (Fig. 5). In contrast, in the PF5 dams, serum and liver IGF-I concentrations were severely reduced by 62 and $80 \%$, respectively, compared with PF20 values, and liver IGF-I 
Table 2. Litter size and indices of growth at birth in pups from dams fed a normal protein diet ad libitum (P20; controls) or a low protein diet (PS) throughout gestation

\begin{tabular}{lcccccc}
\hline Pups & $\begin{array}{c}\text { Litter size } \\
(\text { no./dam })\end{array}$ & $\begin{array}{c}\text { Birth } w t \\
(\mathrm{~g})\end{array}$ & $\begin{array}{c}\text { Liver wt } \\
(\mathrm{g})\end{array}$ & $\begin{array}{c}\text { Protein content } \\
\text { (mg/liver) }\end{array}$ & $\begin{array}{c}\text { DNA content } \\
\text { (mg/liver) }\end{array}$ & $\begin{array}{c}\text { Protein/DNA } \\
\text { (ratio) }\end{array}$ \\
\hline P20 & $9.5 \pm 0.7$ & $5.4 \pm 0.1$ & $0.29 \pm 0.01$ & $41.7 \pm 1.9$ & $1.75 \pm 0.03$ & $24 \pm 1$ \\
P5 & $8.2 \pm 0.4$ & $4.6 \pm 0.1^{*}$ & $0.23 \pm 0.01 \dagger$ & $28.5 \pm 2.3^{*}$ & $1.23 \pm 0.07 \dagger$ & $23 \pm 1$ \\
\hline
\end{tabular}

Values are given as the mean \pm SEM of six to seven litters per group.

${ }^{*} p<0.01$ vs $\mathrm{P} 20$ controls.

$\dagger p<0.001$ vs $\mathrm{P} 20$ controls.

A.

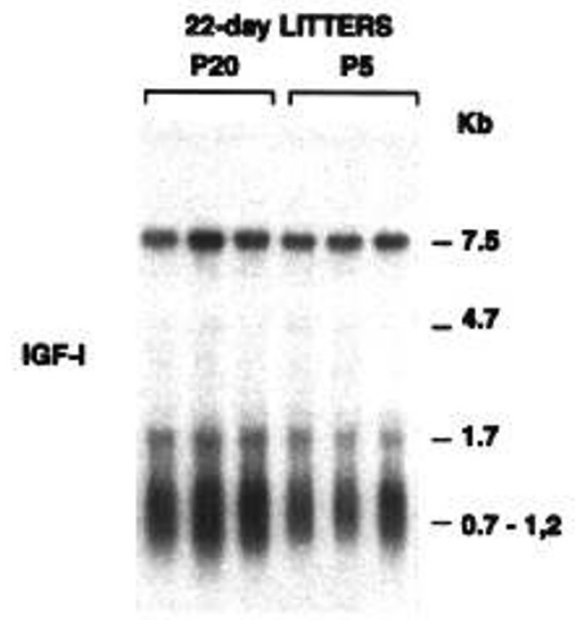

B-Acth

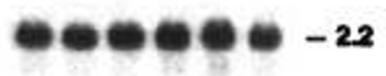

B.
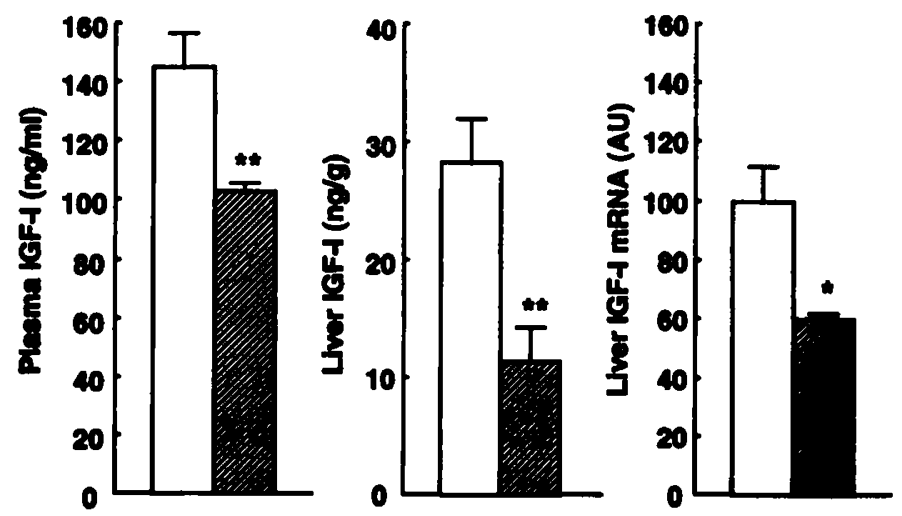

Figure 3. Plasma and liver IGF-I concentrations and liver IGF-I mRNA abundance at birth in rat pups from dams fed ad libitum a normal protein diet $(P 20$, controls) or a low protein $\operatorname{diet}(P 5)$ throughout gestation. Top panel $(A)$, Autoradiogram of a representative Northern blot analysis of liver IGF-I mRNA in P20 and P5 litters at birth. Each lane represents $15 \mu \mathrm{g}$ of poly(A) ${ }^{+}$mRNA from the pooled livers of a litter. The size of mRNA is indicated on the right. Bottom panel (B), plasma IGF-I concentrations (left), liver IGF-I concentrations (middle), and liver IGF-I mRNA abundance (right) in P20 (open bars) and P5 (hatched bars) litters at birth. Values are shown as the mean \pm SEM of six to seven litters per group, except for liver IGF-I mRNA abundance determined on five litters per group. ${ }^{*}, p<0.05$ and ${ }^{* *}, p<0.01$ vs P20 litters. $A U$, arbitrary densitometric units.

mRNA abundance was $49 \%$ less than in the PF20 group ( $p<$ 0.01 ; Fig. 5). Although this decrease involved all classes of mRNA transcripts, the 7.5-kb transcript was the most severely affected $(-87 \% ; p<0.001)$.
By comparing pups from normal protein pair-fed dams (PF20) with those from the ad libitum-fed controls (P20; controls), we could show that the sharp decline in the caloric intake of the rnothers during the last 4 to $5 \mathrm{~d}$ of pregnancy did not cause impaired growth (Table 5). There was also no change in the plasma IGF-I and IGF-II and liver IGF-I concentrations of the pups from PF20 dams, or in their liver IGF-I and IGF-II mRNA concentrations (Table 5 and Fig. $6 B$ ). By contrast, pups from PF5 dams exhibited severe reductions in BW $(-18 \%)$, liver weight $(-24 \%)$, and liver DNA and protein contents (Table 5). Plasma and liver IGF-I concentrations and liver IGF-I mRNA abundance at birth were decreased by 34,54 , and $49 \%$, respectively, in pups from PF5 dams compared with values in pups from PF20 dams (Fig. 6B). All the major IGF-I mRNA species were decreased to the same extent (Fig. 6A). In contrast, there was no influence of maternal protein restriction on neonatal plasma IGF-II and liver IGF-II mRNA concentrations (Table 5). Litter size was also similar among the three groups (nine pups per litter).

\section{DISCUSSION}

Our studies show that protein restriction in pregnant rats causes fetal growth retardation that is evident at birth (d 22), but not on $\mathrm{d} 20$ of gestation. Similar effects on fetuses occurred when pregnant rats were fed an 8 or $7 \%$ protein diet throughout gestation $(35,36)$. These time-dependent effects of maternal protein restriction may therefore reflect a progressive depletion of maternal nutrient stores, which results in an inability to keep pace with accelerated growth at the end of gestation. In other studies, pregnant rats fed a $5 \%$ protein diet from d 7-20 of gestation had decreased food consumption and reduced fetal and placental weights at the end of this period, compared with controls $(23,37)$. Divergence between the latter findings and the apparent lack of effects we observed in 20-d-old fetuses might be explained by the increased food intake of our dams during the first 2 wk of pregnancy. During this anabolic phase of gestation, the protein increments in fetuses are insignificant, whereas the dam builds up a reserve of proteins (38). Conversely, the last days of pregnancy, during which fetal effects of maternal protein deprivation become apparent, correspond to a period of rapid fetal growth and utilization of the maternal protein reserve (38). The increase in food intake in pregnant rats fed the low protein diet ad libitum on $\mathrm{d} 0-17$ and the reduction during the last $5 \mathrm{~d}(18-22 \mathrm{~d})$ has been reported previously (39). Thus, during the metabolic stress of pregnancy, availability of dietary proteins has a strong timedependent effect on food intake. The mechanisms for this are not understood. 
Table 3. Cumulative BW gain, liver protein content, serum, and liver IGF-I concentrations and liver IGF-I mRNA abundance on $d 20$ of gestation in dams fed a normal protein diet ad libitum (P20; controls) or a low protein diet (P5) during d 0-20 of gestation

\begin{tabular}{lccccc}
\hline Dams & $\begin{array}{c}\text { BW gain } \\
(\mathrm{g})\end{array}$ & $\begin{array}{c}\text { Protein content } \\
(\mathrm{mg} / \mathrm{liver})\end{array}$ & $\begin{array}{c}\text { Serum IGF-I } \\
(\mathrm{ng} / \mathrm{ml})\end{array}$ & $\begin{array}{c}\text { Liver IGF-I } \\
(\mathrm{ng} / \mathrm{g})\end{array}$ & $\begin{array}{c}\text { Liver IGF-I mRNA } \\
(\% \text { of controls })\end{array}$ \\
\hline P20 & $96 \pm 6$ & $1352 \pm 98$ & $416 \pm 21$ & $146 \pm 14$ & $100 \pm 9$ \\
P5 & $62 \pm 3^{*}$ & $766 \pm 41^{*}$ & $182 \pm 26^{*}$ & $24 \pm 3^{*}$ & $54 \pm 8 \dagger$ \\
\hline
\end{tabular}

Results are the mean \pm SEM of eight to nine rats/group. For liver IGF-I mRNA, data are derived from the densitometric scanning of three separate blots performed with total liver RNA $(20 \mu \mathrm{g})$ from three rats/group.

${ }^{*} p<0.001$ vs $\mathrm{P} 20$ controls.

$\dagger p<0.01$ vs $\mathrm{P} 20$ controls.

Table 4. Litter size and indices of growth in 20-d-old fetuses from dams fed a normal protein diet ad libitum (P20; controls) or a low protein diet (P5) during $d 0-20$ of gestation

\begin{tabular}{ccccccc}
\hline Fetuses & $\begin{array}{c}\text { Litter size } \\
\text { (no./dam) }\end{array}$ & $\begin{array}{c}\text { Birth wt } \\
(\mathrm{g})\end{array}$ & $\begin{array}{c}\text { Liver wt } \\
(\mathrm{g})\end{array}$ & $\begin{array}{c}\text { Protein content } \\
(\mathrm{mg} / \text { liver })\end{array}$ & $\begin{array}{c}\text { DNA content } \\
\text { (mg/liver) }\end{array}$ & $\begin{array}{c}\text { Protein/DNA } \\
\text { (ratio) }\end{array}$ \\
\hline P20 & $9.0 \pm 1.2$ & $3.4 \pm 0.1$ & $0.25 \pm 0.01$ & $17.7 \pm 1.4$ & $1.59 \pm 0.08$ & $12 \pm 2$ \\
P5 & $8.0 \pm 1.2$ & $3.4 \pm 0.1$ & $0.23 \pm 0.01$ & $15.9 \pm 1.0$ & $1.16 \pm 0.09^{*}$ \\
\hline
\end{tabular}

Results are the mean \pm SEM of eight to nine litters per group.

${ }^{*} p<0.01$ vs $\mathrm{P} 20$ controls.
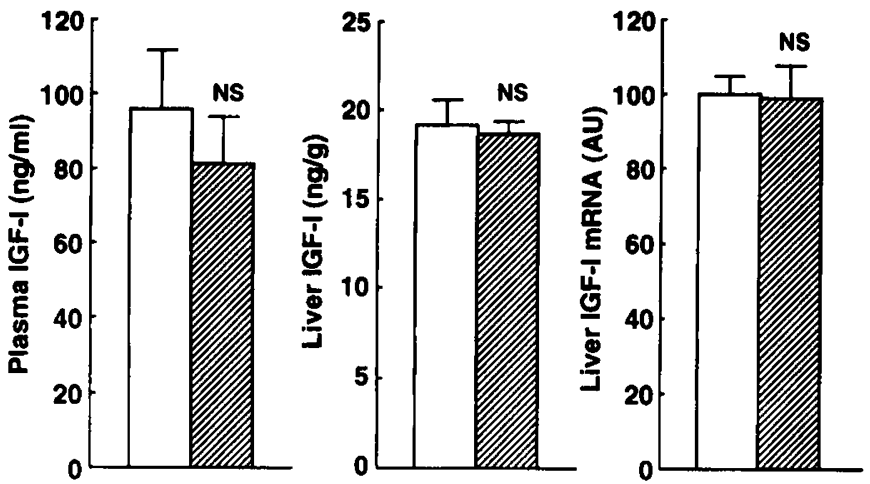

Figure 4. Plasma IGF-I concentrations (left), liver IGF-I concentrations (middle), and liver IGF-I mRNA abundance (right) in 20-d-old fetuses from dams fed ad libitum a normal protein diet (P20; controls; open bars) or a low protein diet (P5; hatched bars) during d 0-20. Values are the mean \pm SEM of eight to nine litters per group, except for liver IGF-I mRNA abundance determined on three litters per group. NS, $p>0.05$ vs $\mathbf{P 2 0}$.

The possibility that lower birth weight in pups from proteinrestricted dams might be due to reduced maternal caloric intake during the last days of gestation, is excluded by our finding that a similar restriction of food intake in dams fed a normal protein diet did not reduce neonatal weight or other indices of growth. This indicates that the retarded growth of malnourished pups is due to protein and not caloric restriction, and confirms the report of Chiang and Nicoll (40) who showed that maternal caloric restriction during the last half of pregnancy does not adversely affect fetal growth or placental weight.

In normal fed rats, there is a dramatic decline in the serum concentrations of IGF-I during late pregnancy (41). We showed that serum IGF-I concentrations are further reduced in dams subjected to protein malnutrition, and that this is due to protein rather than caloric restriction. At least two mechanisms may lead to decreased IGF-I during normal late gestation. First, there is a decrease in IGFBP-3, the principal IGF-I carrier protein in serum, associated with an increase in proteolysis of IGFBP-3 $(41,42)$. This reduces the IGF-I bound in serum, and
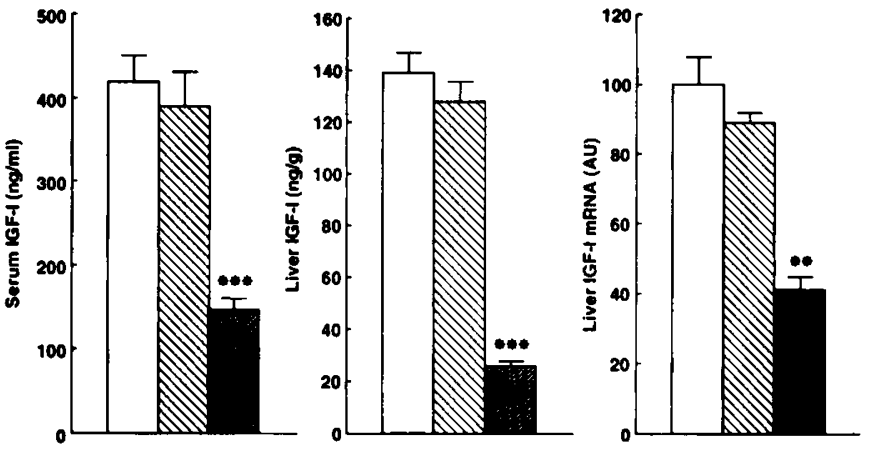

Figure 5. Serum IGF-I concentrations (left), liver IGF-I concentrations (middle), and liver IGF-I mRNA abundance (right) on d 22 of gestation in normal protein ad libitum-fed dams (P20; controls; open bars), normal protein pair-fed dams (PF20; light-hatched bars) and low protein pair-fed dams (PF5; darkhatched bars). Results are the mean \pm SEM of six to eight rats per group. Data for liver IGF-I mRNA are derived from the densitometric scanning of two Northern blots run with four different samples per group. ${ }^{* *}, p<0.01$ and ${ }^{* * *}$, $p<0.001$ vs PF20 dams.

increases its degradation and clearance (40). Second, steady state IGF-I mRNA and peptide levels in liver are decreased in 21-d pregnant rats, suggesting that there is decreased IGF-I synthesis (41). Identical mechanisms operate in the regulation of IGF-I by dietary protein intake $(16-19,43,44)$. Low IGF-I levels in protein-restricted animals are due to reduced hepatic IGF-I mRNA transcription and/or stability $(18,19)$, increased serum IGF-I clearance and degradation (44), and reduced serum IGFBP- 3 concentrations $(16,17,43)$. Thus, mechanisms operative during late pregnancy could become accentuated when the maternal dietary protein intake is deficient. In our study, serum and liver IGF-I peptide and mRNA levels are decreased in parallel in protein-restricted dams. In addition, in 20-d pregnant rats subjected to protein restriction, there is no further reduction of serum IGFBP-3, although their IGF-I is markedly reduced compared to normal-fed controls. Taken together, our results suggest that decreased liver IGF-I gene expression is likely the predominant mechanism for decreased serum IGF-I concentrations in the P5 dams. Our study, how- 
Table 5. Indices of growth, plasma IGF-II concentrations, and liver IGF-II mRNA abundance at birth in pups from normal protein ad libitum-fed dams (P20; controls), normal protein pair-fed dams (PF20), and low protein pair-fed dams (PF5) throughout gestation

\begin{tabular}{lcccccc}
\hline Pups & $\begin{array}{c}\text { Birth wt } \\
(\mathrm{g})\end{array}$ & $\begin{array}{c}\text { Liver wt } \\
(\mathrm{g})\end{array}$ & $\begin{array}{c}\text { Protein content } \\
(\mathrm{mg} / \text { /iver })\end{array}$ & $\begin{array}{c}\text { DNA content } \\
(\mathrm{mg} / \text { liver })\end{array}$ & $\begin{array}{c}\text { Plasma IGF-II } \\
(\mathrm{ng} / \mathrm{mL})\end{array}$ & $\begin{array}{c}\text { Liver IGF-II mRNA } \\
(\% \text { of controls })\end{array}$ \\
\hline P20 & $5.6 \pm 0.1$ & $0.29 \pm 0.01$ & $39.6 \pm 2.4$ & $1.66 \pm 0.06$ & $739 \pm 57$ & $100 \pm 1$ \\
PF20 & $5.4 \pm 0.1$ & $0.30 \pm 0.01$ & $36.7 \pm 1.1$ & $1.58 \pm 0.08$ & $717 \pm 58$ & $101 \pm 6$ \\
PF5 & $4.4 \pm 0.1^{*}$ & $0.23 \pm 0.01 \dagger$ & $28.8 \pm 1.2^{*}$ & $1.17 \pm 0.07 \dagger$ & $763 \pm 118$ & $104 \pm 4$ \\
\hline
\end{tabular}

Values are given as the mean \pm SEM of six to eight litters per group, except for liver IGF-II mRNA determined on two separate blots performed with $15 \mu \mathrm{g}$ of $\operatorname{poly}(\mathrm{A})^{+}$mRNA from the pooled livers of a litter $(n=3$ /group).

${ }^{*} p<0.01$ vs PF20 and P20.

$\dagger p<0.001$ vs PF20 and P20.

A.

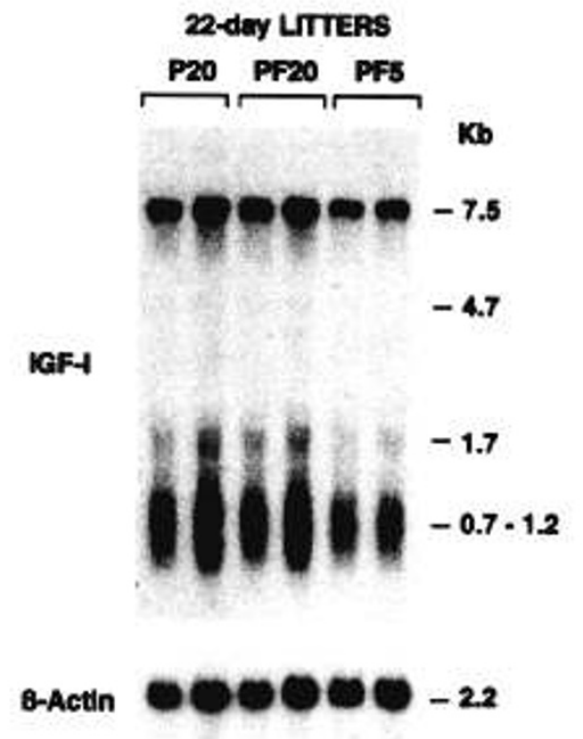

B.
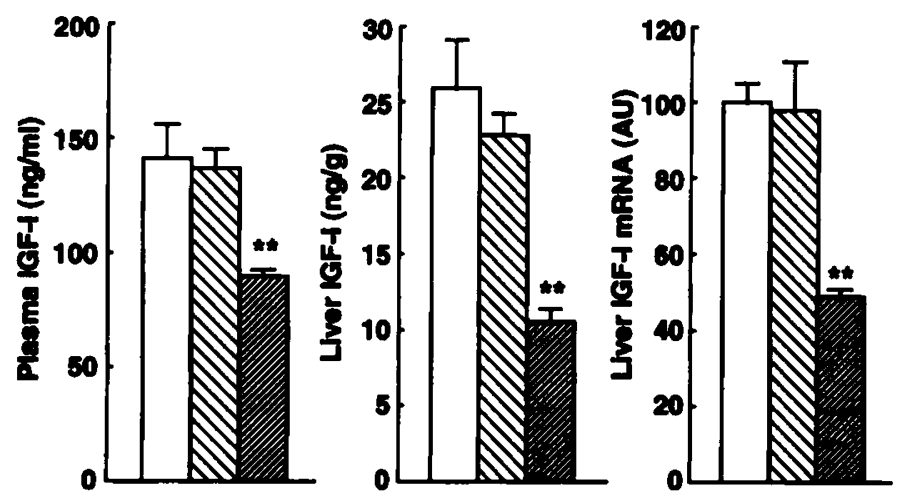

Figure 6. Plasma and liver IGF-I concentrations and liver IGF-I mRNA abundance at birth in rat pups from normal protein ad libitum-fed dams (P20, controls), normal protein pair-fed dams (PF20) and low protein pair-fed dams (PF5) throughout gestation. A, Autoradiogram of a representative Northern blot analysis of liver IGF-I mRNA at birth. Each lane represents $15 \mu \mathrm{g}$ of poly $(\mathrm{A})^{+}$mRNA from the pooled livers of a litter. $B$, Plasma IGF-I concentrations (left), liver IGF-I concentrations (middle), and liver IGF-I mRNA abundance (right) at birth in P20 (open bars), PF20 (light-hatched bars) and PF5 (dark-hatched bars) rat pups. Values are shown as the mean \pm SEM of six to eight litters per group, except for liver IGF-I mRNA abundance determined on four litters per group. ${ }^{* *}, p<0.01 v s$ PF20 litters.

ever, cannot rule out a regulatory role of IGFBP-3 proteolysis, because proteolysis was not assessed directly. Moreover, the Western blot results are not sufficiently sensitive to discern subtle changes, and proteolyzed IGFBP-3 is virtually undetectable by IGF-ligand blotting (45).

The effects of maternal protein deprivation on fetal growth paralleled changes in circulating fetal IGF-I. Body and liver weights, and plasma IGF-I concentrations were not reduced in 20-d fetuses from malnourished dams, but were significantly decreased in newborn pups. Pilistine et al. (23) have also reported decreased serum IGF-I concentrations in the serum of the growth-retarded rat fetuses whose mothers were given a low $(5 \%)$ protein diet for the last $2 \mathrm{wk}$ of pregnancy. Similarly, IUGR in humans (12) and in several rat models of fetal growth retardation (6-11) is accompanied by decreased IGF-I in serum. Taken together, these findings suggest that reductions in IGF-I production and/or availability contribute to stunting of fetal growth. Consistent with this suggestion, are the results from recent studies of Liu et al. (13) and Baker et al. (14) showing that marked growth retardation occurs in mouse fetuses bearing a targeted homozygous disruption of the IGF-I gene.

Our results suggest that decline in neonatal plasma IGF-I may be mediated through decreased expression of the IGF-I gene. Davenport et al. (8) fasted rat dams on d 18-21 of gestation and observed decreased fetal serum IGF-I without change in liver and lung IGF-I mRNA, suggesting that regulation of IGF-I synthesis occurs at a posttranscriptional (possibly translational) step. In contrast, Straus et al. (9) observed parallel decreases in liver IGF-I mRNA and serum IGF-I levels in growth-retarded fetuses from pregnant rats fasted on $d$ 17-21 of gestation. As in our study, this suggests that regulation of fetal IGF-I takes place at the level of mRNA transcription or stability.

Other mechanisms that might account for reduced plasma IGF-I in the growth-retarded pups include reduction of fetal GH secretion, impaired IGF-I release from liver cells or decreased availability of IGFBP. Reduced GH is an unlikely mechanism because IGF are not under GH control during fetal development, primarily because of receptor immaturity (46, 47), although GH receptor mRNA and immunoreactivity are observed in fetal rat tissues as early as embryonic d 12 (48). Clinical and experimental evidence also indicates that $\mathrm{GH}$ is not essential for fetal growth (49), and that the major effect of GH on growth and IGF-I production occurs postnatally (50, 51). Moreover, there was no significant difference in plasma GH concentrations between our control and growth-retarded newborn pups. A secretory defect of IGF-I from liver cells also seems unlikely, because there was no accumulation of IGF-I in 
livers from growth-retarded pups. Finally, although significant amounts of IGFBP (mainly 1 and 2) were observed in the fetal and neonatal circulation, they were not conspicuously altered by maternal protein restriction. Increase in fetal serum IGFBP-1 and liver IGFBP-1 mRNA levels has been reported in growth-retarded fetuses after maternal fasting (9) or uterine artery ligation (7). However, insulin that suppresses IGFBP-1 and-2 (52) was low in these animals. In contrast, similar plasma insulin levels were observed in the growth-retarded and control pups in our study.

Our finding that plasma IGF-II and liver IGF-II mRNA concentrations are not reduced in pups from proteinmalnourished dams is consistent with the observation that fetal serum IGF-II is unaffected in several conditions of IUGR in animals $(7,8)$ and humans (12). Serum IGF-II has been reported to be increased $(10,11)$, decreased $(9,23)$, or unchanged $(7,8)$ in growth-retarded fetuses. These data, along with our findings, suggest that nutrition is not a major regulator of fetal IGF-II expression.

Both circulating IGF-I and IGF-II are acutely and chronically regulated by oxygen and nutrition in utero and mediate, in part, the influence of placental supply of substrate on fetal growth (53). Decreased placental weight and placental IGF-II mRNA/IGF-I peptide concentrations are usually observed in animal fetuses with IUGR $(54,55)$. However, IUGR may be observed despite normal placental weight $(8,56,57)$ suggesting that the ability of the placenta to transport nutrients may be independent of the placental size. Conversely, preserved fetal weight, placental weight, and fetal plasma amino acid concentrations in the presence of maternal hypoaminoacidemia may indicate enhanced placental transport of amino acids such that availability to the fetus is maintained (57). This might partly explain the lack of effects of maternal protein restriction we observed in 20-d old fetuses.

In conclusion, our studies show that maternal dietary protein restriction has marked deleterious effects on fetal growth during late pregnancy. These effects are accompanied by parallel changes in fetal production of IGF-I without change in IGF-II gene expression or plasma IGFBP concentrations. The coordinate decrease in the concentrations of circulating IGF-I and liver IGF-I peptide and mRNA in the growth-retarded pups, suggests that maternal protein restriction modulates fetal IGF-I synthesis at a pretranslational level. Our results suggest that IGF-I may play a role in the regulation of fetal growth.

Acknowledgments. The authors thank Professors P. Malvaux and M. Maes for their help and support. The late Professor A. E. Lambert contributed significantly to the completion of this work. We also thank E. Adam, E. Bruton, P. Selvais, and S. Triest for expert technical assistance.

\section{REFERENCES}

1. Daughaday WH, Rotwein P 1989 Insulin-like growth factors I and II. Peptide, messenger ribonucleic acid and gene structures, serum, and tissue concentrations. Endocr Rev 10:68-9]

2. D'Ercole AJ, Applewhite GT, Underwood LE 1980 Evidence that somatomedin is synthesized by multiple tissues in the fetus. Dev Biol 75:315-328

3. Han VKM, Lund PK, Lee DC, D'Ercole AJ 1988 Expression of somatomedin/insulinlike growth factor messenger ribonucleic acids in the human fetus: identification, characterization, and tissue distribution. J Clin Endocrinol Metab 66:422-429
4. Fant M, Munro $\mathrm{H}$, Moses AC 1986 An autocrine/paracrine role for insulin-like growth factors in the regulation of human placental growth. J Clin Endocrinol Metab 63:499-506

5. D'Ercole AJ 1991 The insulin-like growth factors and fetal growth. In: Spencer EM (ed) Modern Concepts of Insulin-Like Growth Factors, Vol 1. Elsevier, New York, pp 9-23

6. Vileisis RA, D'Ercole AJ 1986 Tissue and serum concentrations of somatomedin-C/ insulin-like growth factor $I$ in fetal rats made growth retarded by uterine artery ligation. Pediatr Res 20:126-130

7. Unterman TG, Simmons RA, Glick RP, Ogata ES 1993 Circulating levels of insulin, insulin-like growth factor-I (IGF-I), IGF-II, and IGF-binding proteins in the small for gestational age fetal rat. Endocrinology 132:327-336

8. Davenport ML, D'Ercole AJ, Underwood LE 1990 Effect of maternal fasting on fetal growth, serum insulin-like growth factors (IGFs), and tissue IGF messenger ribonucleic acids. Endocrinology 126:2062-2067

9. Straus DS, Ooi GT, Orlowski CC, Rechler MM 1991 Expression of the genes for insulin-like growth factor-I (IGF-I), IGF-II, and IGF-binding proteins-1 and - 2 in fetal rat under conditions of intrauterine growth retardation caused by maternal fasting. Endocrinology 128:518-525

10. Jones CT, Gu W, Harding JE, Price DA, Parer JT 1988 Studies of the growth of fetal sheep. Effects of surgical reduction in placental size, or experimental manipulation of uterine blood flow on plasma sulphation promoting activity and on the concentration of insulin-like growth factors I and II. J Dev Physiol 10:179-189

11. Gluckman PD, Butler JH, Comline R, Fowden A 1987 The effects of pancreatectomy on the plasma concentrations of insulin-like growth factors 1 and 2 in the sheep fetus. J Dev Physiol 9:79-88

12. Lassarre C, Hardouin S, Daffos F, Forestier F, Frankenne F, Binoux M 1991 Serum insulin-like growth factors and insulin-like growth factor binding proteins in the human fetus. Relationships with growth in normal subjects and in subjects with intrauterine growth retardation. Pediatr Res 29:219-225

13. Liu J-P, Baker J, Perkins AS, Robertson EJ, Efstratiadis A 1993 Mice carrying null mutations of the genes encoding insulin-like growth factor I (lgf-1) and type 1 IGF receptor (lgf1r). Cell 75:59-72

14. Baker J, Liu J-P, Robertson EJ, Efstratiadis A 1993 Role of insulin-like growth factors in embryonic and postnatal growth. Cell 75:73-82

15. Maes M, Maiter D, Thissen JP, Underwood LE, Ketelslegers JM 1991 Contribution of growth hormone receptor and postreceptor defects to growth hormone resistance in malnutrition. Trends Endocrinol Metab 2:92-97

16. Clemmons DR, Thissen JP, Maes M, Ketelslegers JM, Underwood LE 1989 Insulinlike growth factor-I (IGF-I) infusion into hypophysectomized or protein-deprived rats induces specific IGF-binding proteins in serum. Endocrinology 125:2967-2972

17. Thissen JP, Underwood LE, Maiter D, Maes M, Clemmons DR, Ketelslegers JM 1991 Failure of insulin-like growth factor-I (IGF-I) infusion to promote growth in protein-restricted rats despite normalization of serum IGF-I concentrations. Endocrinology 128:885-890

18. Thissen JP, Triest S, Moats-Staats BM, Underwood LE, Mauerhoff T, Maiter D, Ketelslegers JM 1991 Evidence that pretranslational and translational defects decrease serum insulin-like growth factor-1 concentrations during dietary protein restriction. Endocrinology 129:429-435

19. VandeHaar MJ, Moats-Staats BM, Davenport ML, Walker JL, Ketelslegers JM Sharma BK, Underwood LE 1991 Reduced serum concentrations of insulin-like growth factor-I (IGF-I) in protein-restricted growing rats are accompanied by reduced IGF-I mRNA levels in liver and skeletal muscle. J Endocrinol 130:305-312

20. Donovan SM, Atilano LC, Hintz RL, Wilson DM, Rosenfeld RG 1991 Differential regulation of the insulin-like growth factors (IGF-I and IGF-II) and IGF binding proteins during malnutrition in the neonatal rat. Endocrinology 129:149-157

21. Straus DS, Takemoto CD 1991 Specific decrease in liver insulin-like growth factor-1 and brain insulin-like growth factor-II gene expression in energy-restricted rats. J Nutr 121:1279-1286

22. Zeman FJ, Stanbrough EC 1969 Effect of maternal protein deficiency on cellular development in the fetal rat. J Nutr 99:274-282

23. Pilistine SJ, Moses AC, Munro HN 1984 Placental lactogen administration reverses the effect of low-protein diet on maternal and fetal serum somatomedin levels in the pregnant rat. Proc Natl Acad Sci USA 81:5853-5857

24. Maes M, Ketelslegers JM, Underwood LE 1983 Low plasma somatomedin-C in streptozotocin-induced diabetes mellitus. Correlation with changes in somatogenic and lactogenic liver binding sites. Diabetes 32:106()-1069

25. Lowry OH, Rosenbrough NJ, Farr AL, Randall RJ 1951 Protein measurement with the Folin phenol reagent. J Biol Chem 193:265-275

26. Karsten U, Wollenberger A 1977 Improvements in the ethidium bromide method for direct fluorometric estimation of DNA and RNA in cell and tissue homogenates. Anal Biochem 77:464-470

27. Davenport ML, Svoboda ME, Koerber KL, Van Wyk JJ, Clemmons DR, Underwood LE 1988 Serum concentrations of insulin-like growth factor II are not changed by short term fasting and refeeding. J Clin Endocrinol Metab 67:1231-1236

28. Maiter D, Fliesen T, Underwood LE, Maes M, Gerard G, Davenport ML, Ketelslegers JM 1989 Dietary protein restriction decreases insulin-like growth factor I independent of insulin and liver growth hormone binding. Endocrinology 124:2604-2611

29. Zapf J, Walter H, Froesch ER 1981 Radioimmunological determination of insulin-like growth factors I and II in normal subjects and in patients with growth disorders and extrapancreatic tumor hypoglycemia. J Clin Invest 68:1321-1330

30. D'Ercole AJ, Underwood LE 1987 Estimation of tissue concentrations of somatomedin C/insulin-like growth factor I. Methods Enzymol 146:227-233

31. Chirgwin JM, Przybla AE, MacDonald RJ, Rutter WJ 1977 Isolation of biologically active ribonucleic acid from sources enriched in ribonucleases. Biochemistry 18:5294-5299 
32. Davenport ML, D'Ercole AJ, Azizkhan JC, Lund PK 1988 Somatomedin-C/insulinlike growth factor I (Sm-C/IGF-I) and insulin-like growth factor Il (IGF-II) mRNAs during lung development in the rat. Exp Lung Res 14:607-618

33. Casella SJ, Smith EP, Van Wyk JJ, Joseph DR, Hynes MA, Hoyt EC, Lund PK 1987 Isolation of rat testis cDNAs encoding an insulin-like growth factor I precursor. DNA 6:325-330

34. Whitfield HJ, Bruni CB, Frunzio R, Terrell JE, Nissley SP, Rechler MM 1984 Isolation of a cDNA clone encoding rat insulin-like growth factor-II precursor. Nature 312:277-280

35. Snoeck A, Remacle C, Reusens B, Hoet JJ 1990 Effect of a low protein diet during pregnancy on the fetal rat endocrine pancreas. Biol Neonate 57:107-118

36. Sara VR, Hall K, Menolascino S, Sjögren B, Wetterberg L, Müntzing K, Oldfors A, Sourander P 1986 The influence of maternal protein deprivation on the developmental pattern of serum immunoreactive insulin-like growth factor 1 (IGF-1) levels. Acta Physiol Scand 126:391-395

37. Wunderlich SM, Surendra B, Munro HN 1979 Rat placental protein synthesis and peptide hormone secretion in relation to malnutrition from protein deficiency or alcohol administration. J Nutr 109:1534-1541

38. Naismith DJ, Morgan BLG 1976 The biphasic nature of protein metabolism during pregnancy in the rat. $\mathrm{Br} \mathrm{J}$ Nutr 36:563-566

39. Menaker L, Navia JM 1973 Appetite regulation in the rat under various physiological conditions: the role of dietary protein and calories. J Nutr 103:347-352

40. Chiang MH, Nicoll CS 1991 Administration of growth hormone to pregnant rats on a reduced diet inhibits growth of their fetuses. Endocrinology 129:2491-2495

41. Davenport ML, Clemmons DR, Miles MV, Camacho-Hubner C, D'Ercole AJ, Underwood LE 1990 Regulation of serum insulin-like growth factor-I (IGF-I) and IGF binding proteins during rat pregnancy. Endocrinology 127:1278-1286

42. Hossenlopp P, Segovia B, Lassarre C, Roghani M, Bredon M, Binoux M 1990 Evidence of enzymatic degradation of insulin-like growth factor-binding proteins in the $150 \mathrm{~K}$ complex during pregnancy. J Clin Endocrinol Metab 71:797-805

43. Thissen JP, Triest S, Underwood LE, Maes M, Ketelslegers JM 1990 Divergent responses of serum insulin-like growth factor-I and liver growth hormone (GH) receptors to exogenous $\mathrm{GH}$ in protein-restricted rats. Endocrinology 126:908-913

44. Thissen JP, Davenport ML, Pucilowska JB, Miles MV, Underwood LE 1992 Increased serum clearance and degradation of ${ }^{125} \mathrm{I}$-labeled IGF-I in protein-restricted rats. Am J Physiol 262:E406-E411
45. Holly JMP, Martin JL 1994 Insulin-like growth factor binding proteins: A review of methodological aspects of their purification, analysis and regulation. Growth Regul 4:20-30

46. Maes M, De Hertogh R, Watrin-Granger P, Ketelslegers JM 1983 Ontogeny of liver somatotropic and lactogenic binding sites in male and female rats. Endocrinology 113:1325-1332

47. Kelly PA, Djiane J, Postel-Vinay MC, Edery M 1991 The prolactin/growth hormone receptor family. Endocr Rev 12:235-251

48. Garcia-Aragon J, Lobie PE, Muscat GE, Gobius KS, Norstedt MJ 1992 Prenatal expression of the growth hormone $(\mathrm{GH})$ receptor/binding protein in the rat: a role for GH in embryonic and fetal development. Development 114:869-876

49. Gluckman PD, Grumbach MM, Kaplan SL 1981 The neuroendocrine regulation and function of growth hormone and prolactin in the mammalian fetus. Endocr Rev 2:363-395

50. Behringer RR, Mathews LS, Palmiter RD, Brinster RL 1988 Dwarf mice produced by genetic ablation of growth hormone-expressing cells. Genes Dev 2:453-461

51. Mathews LS, Hammer RE, Brinster RL, Palmiter RD 1988 Expression of insulin-like growth factor $\mathrm{I}$ in transgenic mice with elevated levels of growth hormone is correlated with growth. Endocrinology 123:433-437

52. Suikkari AM, Koivisto VA, Rutanen EM, Yki-Järvinen H, Karonen SL, Seppälä M 1988 Insulin regulates the serum levels of low molecular weight insulin-like growth factor-binding protein. J Clin Endocrinol Metab 66:266-272

53. Owens JA, Kind KL, Carbone F, Robinson JS, Owens PC 1994 Circulating insulinlike growth factors-I and -II and substrates in fetal sheep following restriction of placental growth. J Endocrinol 140:5-13

54. Price WA, Rong L, Stiles AD, D'Ercole AJ 1992 Changes in IGF-I and -II, IGF binding protein, and IGF receptor transcript abundance after uterine artery ligation. Pediatr Res 32:291-295

55. Bernstein IM, DeSouza MM, Copeland KC 1991 Insulin-like growth factor $I$ in substrate-deprived, growth-retarded fetal rats. Pediatr Res 30:154-157

56. Rosso $P 1977$ Maternal-fetal exchange during protein malnutrition in the rat. Placental transfer of $\alpha$-amino isobutyric acid. J Nutr 107:2002-2005

57. Domenech M, Gruppuso PA, Nishino VT, Susa JB, Schwartz R 1986 Preserved fetal plasma amino acid concentrations in the presence of maternal hypoaminoacidemia. Pediatr Res 20:1071-1076 